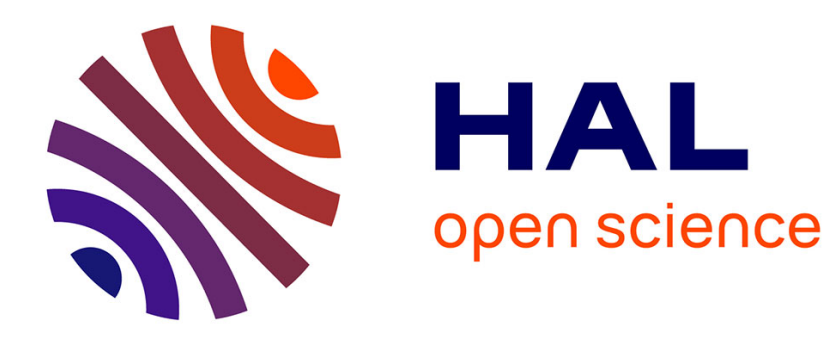

\title{
A people thinning institution: Changing bodies and souls in a commercial weight-loss group
}

Muriel Darmon

\section{To cite this version:}

Muriel Darmon. A people thinning institution: Changing bodies and souls in a commercial weight-loss group. Ethnography, 2012, 13 (3), pp.375-398. 10.1177/1466138111435871 . halshs-02305346

\section{HAL Id: halshs-02305346 \\ https://shs.hal.science/halshs-02305346}

Submitted on 15 Apr 2020

HAL is a multi-disciplinary open access archive for the deposit and dissemination of scientific research documents, whether they are published or not. The documents may come from teaching and research institutions in France or abroad, or from public or private research centers.
L'archive ouverte pluridisciplinaire HAL, est destinée au dépôt et à la diffusion de documents scientifiques de niveau recherche, publiés ou non, émanant des établissements d'enseignement et de recherche français ou étrangers, des laboratoires publics ou privés. 


\section{Muriel DARMON, CNRS}

\section{A People Thinning Institution.}

\section{Changing bodies and souls in a commercial weight loss}

group

Abstract : Some institutions use people as the material of their action and have the project of transforming individuals. This article aims to show that a commercial weight loss group, insofar as its explicit aim is to make members lose weight, is a genuine 'people changing institution', or more specifically a people thinning institution. Based on a 14-month ethnographic study of a commercial weight-loss group, this article analyses how such an organization operates. The article shows that it relies on specific modes of surveillance aimed at controlling the participants' attitudes and behaviors, and insists on the role played by writing and written materials as key tools in enforcing body discipline. It also argues that the change at issue is class-oriented, and more precisely is one oriented towards the middle and upper regions of the social space. These findings have implications for research on institutions, socialization and individual change.

Keywords : BODY - FOOD - HABITUS - PEOPLE CHANGING INSTITUTIONS - SOCIAL CLASS - SOCIAL CONTROL - WRITING. 


\section{A People Thinning Institution.}

\section{Changing bodies and souls in a commercial weight loss}

group

Some institutions use people as the material or as the explicit product of their action (Becker et al., [1961] 2004; Goffman, 1961). Among these institutions, some openly aim at transforming persons. They may be described as 'forcing houses for changing persons' (Goffman, 1961), 'organizations whose explicit mandate is to change them' [i.e. people]) (Wheeler, 1966: 53) or 'apparatus[es] for transforming individuals' (Foucault, 1995). Such organisations thus seek to transform people in a specific direction (in a given area of life) and within a specific scope (from a small change to a radical conversion).

In this article, I argue that a commercial weight loss group, insofar as it explicitly aims at making people lose weight, constitutes a genuine 'people changing institution', and I suggest a sociological analysis of the basis and working principles of such a system. First, I introduce the concept of 'people changing institution' and show the relevance of the term to analyze the way such a system works. Then, I focus on the specific transforming apparatus that the weight loss group I observed constitutes, with two main perspectives. I show that it relies on specific modes of surveillance aimed at controlling the participants' attitudes 
and behaviors in order to have a sufficient hold on them, and I emphasize the role played by writing in this body discipline (for example when members are supposed to write down and count 'everything' they eat or even simply do). I also shed light on the fact that the transformation that is meant to occur is embedded in the social space of class, and oriented towards the upper regions of that space. Lastly, I assess the implications of these results on research on institutions, socialization and individual transformations.

\section{A People Changing Institution}

The power of institutions to transform persons has been a longstanding preoccupation of sociological research. In L'Evolution pedagogique en France, Durkheim already studied the school - more precisely, a Jesuit college - as a mold shaping individuals. Indeed, he described it as a 'system of continous envelopment' (systeme d'enveloppement continu), an 'elaborate method of insiduous envelopment' (savante methode d'enveloppement insinuant) aiming to convert students to the way of thinking and the type of attitude that the Jesuit college requires of them, a deeply homogeneous and univocal 'moral milieu' that 'surrounds' the student and 'follows him wherever he goes' (Durkheim, [1938] 1990: 297-305). Bourdieu and Passeron followed in his footsteps when, in Reproduction in Education, Society and Culture, they wrote about the institution's 
'pedagogic work' necessary for a 'conversion of habitus' (i.e. the radical transformation of an individual and his/her dispositions) to occur - however unlikely it is within the framework of their theory. The institution develops particularly advanced techniques of 'deculturation' and 'reculturation' 'to produce a habitus as similar as possible to that produced in the earliest phase of life, while having to reckon with a pre-existing habitus' (Bourdieu and Passeron, [1977] 1990: 44).

This theme gained prominence in the sociology of the 1960s and 1970s, notably in the US. Two types of institutions, connected but distinct, were distinguished: 'people processing institutions' and 'people changing institutions' (Hasenfeld, 1972).

'People processing institutions' are defined as 'attempting to achieve changes in their clients not by altering basic personal attributes, but by conferring on them a public status' (Hasenfeld, 1972: 256). Their activity thus mainly consists in managing flows of people, and these institutions do not transform people, but rather official definitions of individuals. In his seminal article, Hasenfeld mentioned examples such as a diagnostic clinic, a University admission office, or a juvenile court.

On the other hand, 'people changing institutions', which I will discuss more specifically in this article, 'change the behavior of people directly' (Hasenfeld, 1972: 256): they genuinely transform people themselves, and they do not only make something with people, they make them. Typical examples of these institutions studied in the 1960s and 1970s include schools (Becker et al., [1961] 
2004; Janowitz, 1969; Merton, Reader and Kendall, 1957), mental hospitals (Goffman, 1961; Strauss et al., 1964), prisons and correctional institutions (Adamek and Dager, 1968; Street, Vinter, and Perrow, 1966). Here, I suggest expanding this concept in two directions.

A first shift consists in arguing that the concept can be fruitfully applied to a contemporary context: indeed, it appears just as relevant as it was in the early 1970s. The second shift lies in using a concept mostly used to refer to total, visibly powerful and potentially oppressive institutions, such as mental hospitals in the 1950-60s or prisons, to discuss apparently much more unthreatening and open institutions such as commercial weight loss groups. Initially, it seems to be a bit of a stretch to place these groups where solidarity and self-help are overtly emphasized on an equal footing with the ominous total institutions of the 1960s. Yet, I will show that they are also 'forcing houses for changing people', without negative connotations and without neglecting their openness and respect towards people. Indeed, the commercial weight loss group observed is an organization whose project is to transform individuals. It is explicitly aimed at 'making people lose weight', but this agenda is part of a broader ideology of behavorial modification that relates this transformation to a radical change in the person, as I will show. Their core institutional project is to transform people, and the array of means of control used shows that transforming people is indeed the institution's finality and the legimitizing force of such control.

Such a 'people changing institution' is also therefore a social control institution, albeit a humane one: the activity of transforming people relies on specific modes 
of surveillance aimed at controlling the participants' attitudes and behaviors of members. Where the group highlights individual motivation, will, and selfconstraint as the main driving forces of this transformation, I will show how it actually develops extensive control over the members to reach the goal set.

Furthermore, this transforming project and the control it implies must be considered in light of the social structure they are embedded into, and more specifically must be interpreted as located within the social space of class and class bodies (Bourdieu, 2010). I will demonstrate that although the transforming project is introduced as aimed towards a universal 'good', neutral in terms of social class ('health', 'thinness', being comfortable with one's body), it is effectively class-oriented. I will therefore show in what ways this 'people changing institution' is also a 'people elevating institution' in terms of class: the transformation that is meant to occur is embedded in the social space of social classes, and oriented towards the upper regions of that space.

Both this class orientation and, to a lesser extent, the very existence of this social control activity have received little attention so far. These two elements are almost entirely overlooked in what is, to my knowledge, the only other ethnography of a commercial weight-loss group, published by Kandi Stinson (2001). Stinson's research focuses on three sources of behavior control: (1) society as a whole, through a perfunctory and rather general reference to Foucault's panopticon (Stinson 2001: 8) and a reminder of the social standards applied to women's bodies; (2) the members' 'group', where she claims a necessarily 'limited' surveillance occurs, and that of their family and friends, who 
also exert a partially inefficient surveillance (Stinson 2001: 137-9); (3) last but not least, the 'self-surveillance' carried out by every participant on herself (Stinson $2001: 139-40)$. The focus is therefore more on 'self-control' than on institutional surveillance, with little interest given to class and class variations: group members are briefly presented as homogenously middle-class (Stinson, 2001: 20-3), with no further elaboration.

Some non-ethnographic qualitative analyses may have studied the social control dimension of commercial weight-loss groups. This is the case with the foucaldian approach developed by Cressida Heyes (2006), which insists on the institutional control: 'I have never been in another adult milieu where discipline was applied to such tiny behaviors and deviance greeted with such serious and inflexible responses from the staff' $(132)$ - the normalization the institution exerts on its members and the docility it implies are however balanced by the potential empowerment of the 'care of the self' inherent to the program.. Together with the staff surveillance, Heye emphasizes the role of the organizational 'hypomnemata' ('leaflets handed out at meetings, magazines articles, website materials, and even cookbooks') in this discipline, and I will also show how their written nature has to be taken into account to decipher their hold on members. But in Heye's approach the commercial weight-loss group as a 'site' of control is analysed exclusively in terms of gender, and imposition of gender norms, with no mention of its social class dimension which is to me an important feature of the way it works.

Finally, 'narrative' or 'frame' approaches of commercial weight-loss groups members also study institutional control, but through the specific lenses of the 
power the institution exercizes not so much on what people do as on what people think or say. In his study of Weight Watchers groups, Daniel Martin shows how 'frame alignment within Weight Watchers occurs through the storytelling and emotion work of group leaders, consumption of Weight Watchers literature by clients, and narratives of established members' (Martin, 2002: 174). ${ }^{\mathrm{i}}$ The institution is therefore studied as a 'reselfing' institution — aimed at providing a new and dominant 'frame of rationality' to members —, and not as a 'people changing institution', aimed at actually transforming individual dispositions and practices through external social control. Martin insists on how 'Weight Watchers emphasizes that members are active agents of change, able to transform themselves through adherence to the program' $(2002,183)$, whereas I study the various and precise techniques of social control used to foster such a transformation.

This article will therefore deal with the development and the functioning of the commercial weight-loss group as an 'apparatus' (dispositif), defined as a 'relatively coherent set of practices, discursive and non-discursive, of architectures, objects or machines, which contributes to orienting individual and collective actions in a given direction' (Lahire, 2005). Social control 'in practice' and social class constitute the specific angles through which I suggest to envision such an apparatus. On both counts, my hope is to propose a pertinent outlook on the way such a weight loss group works, but also more generally to contribute innovatively to the sociological analysis of people changing institutions, institutionnal socialization and individual change. 


\section{Methods and settings}

This article is based on data collected during a covert participant observation study, conducted from November 2005 to January 2007 in a commercial weight loss group in France. I chose to go undercover for mainly practical reasons, and because it seemed to me the ethical drawbacks were in this case minor. Having registered during a maternity leave when I was more than happy to join the program, I felt that the group (part of which stayed the same, part of which changed from week to week) would be more disturbed than usefully informed by a repetitive and solemn declaration of observation that I would have had to make each week. Furthermore, it seemed to me that although group meetings create a form of intimacy, members are always aware of the public character of anything they could say (once again, each week the group may be composed of different persons, some of them one knows from the weeks before, some of them one doesn't, some of them one will see again, some of them one won't, etc.). Although discussions concern day-to-day life, they mention extremely rarely more private things than taste for chocolate or cooking tips, one's occupation or marital status being the most probable personal elements to appear when discussing constraints to the diet. Concerning more specifically the absence of disclosure to the leaders and the company itself, I thought that the disclosure of my observation could really alter the usual relationship between leader and member I wanted to 
study from my own experience, and I was also afraid of being driven to disclose my observation to the leaders and not to the members, creating a dissymetry which would be in itself a problem. To sum it up, I chose to go undercover because I was actually participating in the program, because it seemed to me it was difficult to be totally and always overt for everyone, because there was no possibility of harm to those being studied, and finally because research benefits largelly outweighed this small compromise of participants' knowledge (Murphy, Dingwall, 2001: 342).

As a result of this decision of using participant observation, I attended one or sometimes two weekly meetings, led by Martine and more rarely by Fabienne. The commercial weight loss group I observed is organized around a weekly meeting, accessible to paying members only, which works both as a support group and as a collective class taught by a 'leader', a former customer who was selected, trained and then employed by the company. Each week, upon their arrival, members (mostly women) are weighed by the leader, who meticulously writes down their weight and its evolution, and gives them documents that complement the companion books and written methodological material that they received when they joined the group. Members may also purchase certain objects required for the diet (cooking books, kitchenware, preparations, various companion books).

Before the meeting starts, members stand in a long line leading to a screen that conceals the leader and the scales. When she gets off the scales, the member comes back with various dieting documents: a blank food journal to write down 
daily food intake, a small information sheet on a specific theme, or even, once a month, a 'brochure of the month' containing advice, recipes and simple explanations of the program's underlying behavioral theories and motivations. On the scheduled time, the 'session' begins. Members are seated on rows of chairs, facing a board in front of which the leader stands and starts discussing the day's theme. She then proceeds to make as many members as possible 'participate', asking them to provide input or commenting on their remarks or questions.

The diet itself consists in controlling the calories and lipids ingested through the management of a personalized daily total of 'points' attributed on the basis of a questionnaire filled in by every member upon joining (taking into consideration age, gender, weight and physical activity). Several companion books or calculators can be used to find the equivalent of each food intake in points, that subsequently have to be subtracted, meal after meal, from the total amount allowed for a day, and the worth in 'bonus points' (that can be added to the normal daily total) of a given physical activity. Every piece of food ingested is anticipated and taken into account: it is both counted (in the total of points available in a day and in a week) and written down (in an extensive food journal, which works as a constant reminder of the standards to be met). Physical exercise gives access to an additional number of points that has to be measured with great precision, using a cardboard slide rule, according to a chart where the type of activity, its intensity, the individual's metabolism (assessed on the basis of weight) determine the number of points 'gained'. 
In the early stages, as members learn the ropes of the diet, this point system when it is dutifully followed - is a major preoccupation: indeed, they have to think about the organization and the composition of the meals, to ensure quantitative compliance with the number of points by anticipating the next meals, to check that the other qualitative principles of a balanced diet are also respected, and to count physical activities. Lastly, while the diet allows eating out (the Dining Out Companion helps members assess the number of points of the main restaurant dishes), members are strongly encouraged to cook for themselves with countless recipe books sold during meetings - as a consequence a significant amount of time is also devoted to cooking in addition to the time spent planning meals and physical activity.

As a participant observer, I took notes during all the meetings I attended (other members sometimes wrote down recipes or information on small notebooks like mine), kept a field journal after the meetings. I also collected the extensive written organizational material available during the meetings and on various websites, which I used to assess to what extent what I saw was specific to the meetings I attended or more ubiquitous. As with the choice of attending meetings hosted by two different leaders, this enabled me to isolate in this article social mecanisms and processes that I believe are not specific to the particular setting of my observation but much more general to the way the institution works.

All of the following excerpts are drawn from meeting observations recorded in this field journal, and all the names used are pseudonyms. Ultimately, the study should also include interviews with members and consider the issue of bodily 
careers within and outside of systems like the one under review, but as of now the material is exclusively drawn from organizational material and observational data.

This provisional restriction of observation to the system, rather than to the members themselves, is decisive with regard to the construction of my object. Indeed, in this article, I will not study the actual effects of the system on the members' behaviors; nor will I take into account the members' positions towards the system, or their degree of support or compliance with its demands. I plan to address only in a second stage of the research a key question in the sociological analysis of 'people changing institutions'- that of the scope of the effective transformations that occur and their congruence with the project and institutional program of the transformation. Accordingly, I keep for later the question of whether individuals assimilate institutional demands or are transformed in ways that differ from what the institution has planned for them (Becker, 1968), or whether an institution's socializing effect hinges on variations derived from the combination of the institution and people's former social properties (Darmon, [2006] 2010). These delimitations enable me to focus for the moment on the institution itself and the kind of control it deploys and wishes to exert. Such a twostages analysis, and the concentration on the institution it allows in its first step, may well be very useful to avoid being engulfed in the analysis of what members do 'with' the institution, how they see or interpret it, which may lead to unsufficient knowledge of the way the institution works or even to underestimate the actual institutional control and influence over individuals, with which this article deals. 


\section{Discipline and Famish}

Members have to pay to attend these meetings. They have to spend a lot of time planning, preparing, counting and regulating their food intake. They have to organize their life, or at least part of it, around the 'program' and its dictates. This raises the social and sociological question of how to obtain such an investment from a single 45-minute-long weekly meeting. While spontaneous representations tend to describe this involvement in terms of 'will' or 'motivation', I will conversely shed light on the control exerted over individual conducts, by focusing on the implementation and the techniques of institutional control.

\section{Denying control}

The issue of the control exerted on members is very present in the group's shared representations, and elicits both positive and negative connotations. The institution evidently works hard to counter these representations of violence and oppression that it perceives to give a bad or outdated image of itself. Various figures suggesting the idea of a totalitarian control over people, such as the cult, the humilating punishment, or public weighing, are explicitly rejected by leaders: 
During one of my first meetings, Martine asks the crowd: 'What image did you have of the group and of the meeting before you came here?' Members obviously and knowingly give her the answer she is expecting: 'I thought you got a dunce cap when you gained weight!' 'I thought if you gained weight you had to stand in front of everyone and have them laughing at you!'... Martine picks up on these answers and ostensibly goes through a list of images that she dismisses as wrong: 'we weigh you in public', 'we're a cult'....

Hence, leaders explicitly distance themselves from anything that might make the meeting resemble a 'degradation ceremony' (Garfinkel, 1956) and make the control exerted over conduits seem oppressive or humiliating. The frequent reminder of weight loss as a limit to institutional intrusiveness can also be interpreted similarly. Indeed, leaders emphasize the fact that 'as long' as members lose weight, they do not have to 'intervene', to 'criticize', i.e., control the modalities of weight loss. 'Loss-based' control thus amounts to a 'result-based' or objective-driven control, which shows members that control in itself is not a goal for the institution, and that the latter intervenes only if the member does not manage to reach her own goals:

[During a meeting] Carmen is a former member, who lost around 45 pounds a few years ago and is now coming back to the meetings because she has regained weight. She says that this time, she does not write anything down but that the diet is working anyway, she's lost two point eight pounds this week and 13 since she started (she apparently does roughly assess her 
number of points). Martine tells her that as long as she is losing weight, there is no point in creating constraints for her, if it is working and she is happy with her weight loss. However, if she was to stop losing weight... Martine smiles, and everyone in the room 'hears' the ellipsis!

Yet, as this example already makes clear, this institutional restraint reasserts the very principles from which it claims to move away. No control is exerted over procedures if they are in practice deemed to be efficient, but this means that failing positive results, an intervention is made even more legitimate and is accepted tacitly and unreservedly by the member. Even in cases where the institutions explicitly denies a posture of control, the latter still hangs over members like a sword of Damocles. Thus, even when the institution seeks to distance itself from the totalitarian connotations of the control it exerts, the 'institutional program' as a mode of control is not questioned. It is also all the more visible as, generally, leaders do not shy away from pointing out that the institution's raison d'etre is precisely to exert such a control, and that its backbone is the ability to manage and govern conducts: 'In part, what these clients pay for is organizational surveillance' (Martin, 2002, 170).

\section{The leader: cop or judge?}


The leader exerts the most explicit form of control. This materializes notably in the long waiting lines leading up to the screen behind which the leader is standing next to the scales, and even in the members' mise en scene of fear and suspense in these lines. This is an obvious control that is asserted as such and partly functions in a performative manner: its utterance and visibility contribute to its very existence and power. By reminding members that they are controlled, the institution makes sure that it controls their behaviors. Even though efforts are constantly made to dismiss the idea of a totalitarian surveillance, many references to a self-actualizing control are made:

- To a member who is dramatizing her fear of the scales' 'verdict' even though she also says that she should not 'be afraid' because she has already weighed herself at home, Martine points out: 'It's not the same thing, right, when you weigh yourself at home? It's never the same. At home, Martine's not standing behind the table...'.

- 'The meeting is the time to evaluate, the moment of truth, the judge behind the table', Martine says during the meeting. A member in the room interrupts: 'it's the cop!', but Martine rectifies: 'I like the judge better than the cop, the judge comes after the cop, you're the cop at home all week.'

- [During my initial session] Before I leave, I ask the leader and the meeting 'secretary' if I can come to any meeting during the week. The secretary replies that there are meetings everywhere in the entire country, and that if I want to, I can go to one in 'Nice or Marseille' (if I'm on holiday there, it is implied). 'There are meetings everywhere, we follow you!', Martine adds. 
Her colleague playfully points out that 'we follow you, that sounds a bit like surveillance!', but Martine laughs and repeats 'We're everywhere!'.

Indeed, there is a subtle balance between the enunciation of a strong control, as the first token of its efficiency, and the distancing from a totalitarian model. In the aforementioned examples, this balance is achieved either through humor or through the definition of a 'justice'-oriented role rather than a police-oriented one, which implies that the strongest control lies in the internalization of control (being one's own cop) and that the leader's role is to enforce justice after the fact rather than to control constantly.

The observating of the meetings, however, reveals the application of an actual control of conducts by the leader: the 'judge' does not merely 'come after' the cop, rather, she effectively controls her activity:

Twenty minutes or so into the meeting, a member sneaks in to get weighed and attempts to sneak back out immediately... Martine interrupts what she was saying to the members, and calls out at her, asking if she has lost or put on weight: Simone, with a hint of provocation, answers that she has regained weight. Then Martine starts lecturing other members, while Simone remains stuck between the last row of chairs and the door, about to leave but stopped short by Martine's speech, which is meant both for her and the others' benefit: Simone 'does 45-point-days' [NB: This is more than twice most members' average amount, and probably twice more than what she 'should' be doing according to the program], and the problem is that, as a result, she is placing her health at risk, Martine says. Frédérique, a 
member in the first row, gets involved: 'in that case, I really don't see the point of her coming here if she's going to do this!'. Martine then defends Simone (and the company!) by arguing that members can have two different types of approaches, one of them being to come in order not to put on too much weight. Simone, still standing by the door, says to the group: 'The thing is, I'm not aware that I'm putting my health at risk.' Martine concludes the interaction by telling Simone: 'next week, bring me your food diaries [her tone evokes the way a schoolteacher asks a pupil to show her his homework], we'll have a look at them. I don't even need to write it on your card [each member's weight is written on a card on a weekly basis; this card is also used as a medium of communication for the different leaders when they switch meetings] I'll remember it.' Upon seeing Simone's disheartened look, she adds: 'This is not a punishment, Simone, this is just meant to help you. And maybe since you'll have to write everything down, you'll eat a bit less...'

Such an interaction constitutes a slightly unusual moment of control over a member who is unwilling to submit to it and has tried to avoid facing the leader. But the leader's control over members actually occurs on a continuous, daily basis, as does the members' play with this control. In the leader's view, it is necessary to be crafty because the members use stratagems themselves:

Before the meeting, two members are chatting behind me. They agree that the Saturday morning is convenient because 'it's far from the weekend for the weight, the weigh-in', 'we've got all the time during the week to lose 
weight from the weekend's excess', 'those who have meetings on Monday can't do that!'. I am under the impression that Martine is eavesdropping on this conversation (although it is muffled and difficult to hear) but I cannot be sure, until during the meeting, Martine 'happens' to mention this theme, although today's topic is entirely different. Martine says that she has made 'statistics' on all the meetings and the weight losses, and that those who lose weight more quickly are those who attend the Monday sessions, because they have to watch what they eat during the weekend, and as a result will not have two helpings of the dish they are served when they are invited because they think to themselves 'tomorrow is the weigh-in!'.

The games of deception and control are clearly visible in this excerpt, since tales of scheming and resistance to institutional control overheard in a meeting are used by the leader as part of a new wave of institutional control and themselves become the object of a control that takes advantage of their utterance to be expressed whether the members are aware or not that their conversation has been heard.

\section{Pushing the institution's limits}

The leader's direct control, however powerful, knows temporal and spatial bounds. According to Hasenfeld (1972: 258), the 'long term' character of the relationship between staff and client distinguishes 'people changing institutions' 
from 'people processing institutions'. In the present case, however, two minutes of face-to-face interaction during the weigh-in and a 45-minute-long group meeting is not much time to ensure a control whose effects should be felt on a daily basis. Hence, the leader enlists allies in institutional control, whose effect is to push the limits of the institution and its influence outside of the meeting room and the leader's sphere. This arguably aims at 'totalizing' a non-total institution, if Goffman's notion (1961) can be understood not as a property of the institution itself but as a dimension of its action. There are three types of recruits: comembers (other members of meeting groups), significant co-members (whom the member was familiar with before joining and with whom she joined) and friends and relatives, who belong to the member's domestic circle. ${ }^{\mathrm{ii}}$

Through the meetings' collective character and the sharing of individual experience, co-members constantly act as a virtual group of constraint and control, whether this constraint is softened by an asserted solidarity or takes on agonistic accents:

- Fabienne is doing 'Martine's meeting' today. Towards the end of the session, she speaks to two new male members who are coming for the second time, Frédéric and Bernard. Fabienne asks both about their target weight loss: 'about twenty pounds', answers one of them, who has not lost any weight this week and quickly admits that he actually does not count points ('anyway, I have the dish of the day for lunch at the restaurant everyday, so...') and does not fill out the food journal. Fabienne advises them to keep the food journal everyday. Bernard says that he will try to do it 
in the evening, because it is impossible at lunch... Sylvie, another member, then interrups to suggest that he should not do it too late: 'well, if it's in the evening, you have to do it before dinner, because otherwise it's pointless! If you realize that you've had 30 points after dinner, it's no use! It has to be before dinner.'

Fabienne approves and adds 'I can understand that you don't want to take out the journal when you're eating out with your colleagues, but Sylvie's giving you some good advice there.' She asks the crowd: 'So, are you ready to write those diaries?' 'Yes', they answer in a slightly contrived manner. With a sarcastic smile, Fabienne tells them: 'Well, if you're so eager to do it, it'd be a shame not to look at them next week!' 'Hey, that's nasty!', a giggling member says. Fabienne is also smiling, but (in my opinion, responding to this remark, fearing that her latest repartee might have been perceived as overly humiliating) she smooths out the edges by endowing Frédéric with the power of breaking from the shackles of institutional control: 'Right now, Frédéric's thinking "Yeah, right, next week, I'm not coming, so I don't care!” The audience laughs again, but this time she has emphasized his power to back out, not her power to control.

[The following week, Martine is in charge of the meeting again as usual]. Frédéric is in attendance; he speaks up to say that he is unhappy with his weight loss - he has only lost about one pound even though he has been carefully monitoring his food intake. A member then interrupts to tell Martine: 'you should ask him if he's written it down, because last week, he 
didn't and Fabienne told him she would check!!' Everyone laughs, and so does Frédéric, saying: 'hey, I think there's a rat!'. Sylvie, in the spirit of last week's intervention, contributes by expressing her support to Frédéric very earnestly: 'It's hard when you eat out at lunch, but it's good, it's one pound less already after all, that's something.'

While the official discourse advertizes member solidarity, the group, as in the case above, can also explicitly work as a control group and as the leader's allseeing Argus, and 'telling on' other members is not particularly discouraged. In fact, the institution uses and even fosters competition between members, which plays a major role in keeping them on track. Competitions are regularly organized, for instance non-compulsory 'challenges', where each member is encouraged to write their target weight loss ('before early May', 'until Christmas') on a board in the middle of the room, and to record their weekly progress and compare it to the others' - those who win the challenge, i.e. those who have achieved their target, win a gift.

Aside from this anonymous competition where everybody can 'win', there are more individual and agonistic forms of competition. Indeed, future members are encouraged to do the program 'together' (which obviously leads to an increase of the number of members) or to sponsor other members: thus, within the meeting groups, there are pairs or sub-groups of 'significant' members (like Mead's 'significant others', they are characterized by their family or friendly relationships) that existed prior to joining the group. This implies obvious 
advantages in terms of mutual support, but also in terms of emulation, which the leader may sometimes point out in rather crude terms:

A mother and her daughter, both members, are attending the meeting. The daughter has lost weight two years ago, and has not regained it since. Martine asks the daughter her 'motivation for maintaining this weight for two years'. 'Doing better than my mother!', she replies. Martine then goes on to say that it is good that the two of them are coming together, that competition is a driving force, and that they should keep up this 'challenge': 'it's a lovely war between mother and daughter', she concludes cheerfully.

In such situations, the institution thus extends its reach, insofar that it inhabits or colonizes pre-existing relationships to turn them into delegated venues of control. Beyond the leader herself and the meeting room's walls, the institution, observed as an institution of control, expands to the extent that it enlists people with whom it does not even have any contact and who constitute allies of the institution 'in the field', and offer an opportunity to control everyday life:

[Martine, during a meeting:] You shouldn't eat on the sly, because otherwise you eat quickly, and since nobody's seen you, you eat some more, whereas if you eat in public, a piece of chocolate for instance, someone will tell you 'you shouldn't eat that, with your diet', and you can say 'yes, I can, and actually I'm going to write it down right now', and then you write it down and you don't eat any more, because otherwise, they're going to tell you 'well now you're pushing it a bit, aren't you?'. 
The boundaries, both social and spatial, of the institution, and of its power of coercion, are thus not predetermined. The institution specifically works to extend them, and I argue that they are shaped and crystallized as a result of the interaction between this institutional work, the members' predispositions, the properties of their domestic environment and their uses of the institution.

\section{The written delegation of control: a panopticon on paper}

This extension of the institution does not solely rely on the ultimately unpredictable recruitment of allies in everyday life. One of the basic foundations of the program and a cornerstone of the long-term application of such remote control is the written word.

The importance of writing in the meetings and the program as a whole is quite remarkable. This can be partly explained by the current influence of cognitivebehavioural and motivation theories. The latter have recourse to daily writing in order to foster awareness of behaviours, to materialize commitment towards oneself and others and to provide a basis for the therapist's work. More generally, the increase in 'written instructions' is a feature of 'modern information societies' (Tomlinson, 1986: 202).

Group members are indeed very frequently reminded of the necessity of writing - be it a specific member or the group as a whole: 'When you hold a pen in your 
hand, you're losing a pound', 'Write and you'll lose some weight', as Martine often says during meetings. Indeed, members have to 'write down' and 'count' 'everything', every food intake or activity. Writing 'everything' down may also include keeping track of resolutions or self-commitments, also in accordance with behavioural prescriptions:

[Martine, during a meeting] You have to make a resolution to move. You have to make a precise schedule and write down the physical activity you are planning to do, 'I'm going to do this, I'm going to do that', and you put exercise in your free time slots, otherwise you end up doing nothing, if you don't write it down, you don't go and do it.

Likewise, 'you have to read': on their first day, new members are mostly told what to read, how to read, and in which order to read the diverse written materials they have been given - in a large folder or in a bag - upon joining. With each weekly meeting comes a new collection of small leaflets and various texts, and each month there is a new thematic 'brochure', a sort of pocket-sized magazine including texts, illustrated testimonies, pictures and recipes. Leaders encourage members to read these advice 'brochures', but also to consider recipe books as actual, 'educational' reading (acquiring new skills, finding out about new recipes) or 'fun', and not only as practical or utilitarian reading, merely meant for the kitchen table: 'You know, when I'm not doing well, I take the cooking books and I read them, and then I feel better already' (Martine).

The importance of the activity of writing suggests looking at the group observed, like the laboratory studied by Latour and Woolgar, as an organization 
that spends most of its time 'coding, marking, reading and writing', as a 'system of literary inscription' 'transform[ing] pieces of matter' (here, food, flesh, practices) 'into written documents' (Latour and Woolgar, [1979] 1986: 51). Yet, here, the written word is also the evidence and the mediation of power, which Latour and Woolgar's analysis tends to overlook. Writing is clearly part of the apparatus of control I analyze, first as an explicit self-control tool. Indeed, at the individual level, writing is meant to work as a substitute for practical sense (Lahire, 1998) and to develop or replace missing or faltering dispositions to lose weight. Keeping a food journal on paper is meant to orient practices by keeping members from going down the slippery slope of 'bad habits', and an attempt to leave behind the old dispositions (guiding behaviours internally) defined as bad by writing practices (guiding behaviours externally). Then, the method aims at replacing the old dispositions by new ones. In particular, 'points', which are first and foremost an institutional fiction, ultimately become a completely internalized and normal way of grasping reality, something that can be seen and felt:

- After a member has explained that she has eaten out several times this week but yet managed to lose weight, Martine asks the crowd: 'What did you do, before you were in the group, what did you have?' Several members laugh and reply: 'anything we wanted!'. Martine goes 'Yes! And what do you do now?', and the room answers: 'We calculate! We calculate!'. Everyone laughs, and Martine hammers the point home: 'Now when you read a menu, you can really picture the points, can't you?' - several 
members concur: 'yes, yes, that's it!' 'you can picture them next to the price of the dishes!'.

- Before the meeting starts, I overhear a conversation between two members sitting behind me, that I would never have understood back when I started the observation. This is rapid-fire shop talk: 'If you find 30\% [fat] cheese spread, for one-half [points] you have roughly a small eggcup, two eggcups are one [point], and you spread it on filling potatoes [i.e. boiled potatoes, taken in 'reasonable' quantities in order to trigger satiety signals], so that's three [points].' This echoes the leaders' public prowess: they count points for a given meal or a specific food at the speed of light, without any help from written guides. Most fittingly, Martine, the leader, is a former accountant, as she has repeatedly pointed out to us!

The way the members 'think in points, and eat in points' can thus be explained by the existence of a very explicit work on dispositions, relying on the writingreading-counting trinity, which effectively produces the incorporation of a specific practical sense. ${ }^{\text {iii }}$

However, in addition to this function of self-control and of substitute for practical sense, the trinity plays a second role, more inconspicuous but no less significant: that of an instrument of external control and of a substitute for the panopticon (Foucault, 1995).

This is the case of food journals, which are used by the leader to control the members' food intake directly or indirectly (through the threat of control, and aforementioned injunctions such as 'show me your journal'). More generally, the 
written word works as a keystone of the surveillance system - it is so ubiquitous that one no longer notices it. Indeed, from the first day, members are snowed under with written words and numbers. There are things written everywhere in the meeting room: on walls, panels, posters (testimonies or rules) and on the board, or in books, brochures and information sheets handed out to members. Among the 'objects' available for sale on the large table set in the middle of the room, very few have no direct relationship to writing or numbers (including cereal bars, matter-of-factly called '2 Points!'), except perhaps a rubber band for exercising purposes and a silicone cake pan.

This avalanche of writing continues with a flow of written materials from the meeting room to the members' homes, which become extensions of the meeting room and places of writing. In a member's home, one may indeed find the weekly food journal, the weight tracker which charts the progress in weight loss from week to week according to the target set, various companion books (Food Companion, Dining Out Companion), sometimes an electronic calculator, cooking books, brochures, old journals meant to be kept as reference for filling new ones. This 'paper surveillance' is therefore a constant one, insofar as the ubiquity of writing creates a continuity in institutional action that goes far beyond that of the interactions between members, the leader's gaze and physical co-presence. This mass of paper may be stored at home (the complimentary bag given to members upon joining is visibly meant to be used for that purpose and quickly overflows with papers), but much of this written material must be used frequently if the program is dutifully followed, and members cannot just tuck them away in a 
corner and forget about them: they need to keep them at arm's length, where they can see them, and so they work as reminders of the authority of writing. The written word, much like the panopticon analyzed by Foucault, thus 'intensifies' the institution's power over conducts, and seeks to induce in members a 'a state of conscious and permanent visibility that assures the automatic functioning', and the deindividualized functioning of power, so that 'the surveillance is permanent in its effects, even if it is discontinuous in its action', it creates a 'field of visibility' in which members locate themselves and use the constraints of power to their own advantage, make them spontaneously work on them, and carve in themselves the balance of power in which they play both roles simultaneously (Foucault, 1995), the member and the leader.

A substitute for practical sense and for the panopticon, the written word is, on an even more fundamental level, the backbone of the production of a new world for members. This is first because, like any other form of shaping reality by listmaking (Goody, [1977] 1995), the written word in the group reorganizes reality based on new ranking criteria (the number of points assigned to specific foods or meals), constitutes categories for grasping reality based on new hierarchic principles (at the end of the cooking books, recipes are ranked in ascending order according to their equivalent in points). Including through recipes, which work as written constraints (Goody, [1977] 1995) aimed at making members learn to cook again, i.e., cook in a different manner, the written word is meant to make members acquire new skills, and give them access to another culinary world, one that is entirely controlled by the institution. In addition to these new classification 
systems and new skills, there is also a process of definition of the members' world through the delimitation of a space of possibles. At home, 'when you don't know [how many points a given food or meal is worth] you don't eat.' Restaurants that are not part of a category included in the Dining Out Companion, which lists fastfood joints, cafeterias, specialty and exotic places, are de facto excluded from the list of practical, easy or even possible restaurants; a type of physical exercise that is not mentioned in the official list is not exercise, since it does not allow for calculating and subtracting points. Hence, what is not written down does not exist. The written delegation of control is particularly radical in this respect, insofar as it can come to a total control of the members' world, and make the written world it develops 'the world, the only existent and only conceivable world, the world tout court' (Berger and Luckmann, [1966] 1991: 154).

\section{Class Conversion}

The weight loss group is, however, much more than just a thinning machine. Using mainly Bourdieu's Distinction (2010) and empirical updates, I will argue that this enterprise of normalization of corporal deviances is also an industry of conversion of lower-class habitus into a middle-class one.

As far as class origins and occupations are concerned, I will gather much more data on members in future study. But observations made so far suggest that 
althought the group seems quite diverse, a significant part of the members are from working-class or rural backgrounds and seem to fight, or be willing to fight, working-class or rural habits. Here I will argue that the institution is primarily aimed at this kind of audience through its class conversion orientation. As is is often the case with institutions aimed at transforming bodies, the weight loss group is, as the gym studied by Wacquant (2004), a 'school of morality'. What is taught - and probably what is learned - largely exceeds food and body practices and values, and has to be located within the social space of social classes to be fully understood.

Its patent function - normalizing women's eating and bodily deviances - is indeed also embedded in a social space where dieting itself is a socially cleaving practice, just as thinning means, for women, climbing up the hierarchy in the social space of bodies, since the higher one's social origin and occupation, the lower one's weight (Darmon, 2009; De Saint-Pol, 2010). Furthermore, in the recipes suggested in weekly or monthly brochures and cooking books, exotic foods, fish and seafood, fruits and vegetables are very frequent: this can be explained by the compliance with standard dieting dictates, but also constitutes an injunction to adopt food habits that are specific to middle and upper classes (Bourdieu, 2010 ; Régnier, Lhuissier, and Gojard 2006). Therefore, members are supposed to embark on a journey which is an upward trajectory within the 'food space' and the 'universe of class bodies' (Bourdieu, 2010: 182-91).

Yet, the action and even the - sometimes explicit - aims of the organization cannot be reduced to this alimentary and bodily function. Meetings may be used 
my members as places of sociability (I will not discuss this point here) or as places to learn about dieting and cooking, but on a more latent level, they also work as venues of moralization. The institution, indeed, aims at regulating the members' lives far beyond weight issues only, even though this is presented as the main aim in its various fields of action. As far as class values are concerned, it upholds self-restraint, frugality as a way of life, compliance to the diet and independance from family or collective rules that could prevent it. In doing so, it works hard to transform members' working class dispositions into middle-class ones, and it displays 'the break' of middle-class sobriety defined by Bourdieu: ‘ abstaining from having a good time [as an] ambition of escaping from the common present', abstinence over intemperance, and individual salvation over collective solidarities (Bourdieu, 2010: 179-80).

The action of the institution on the members' eating practices goes further than the injunction to lose weight; members are also urged to cook for themselves more, to try varied recipes with the help of the books sold to them. During meetings, leaders talk about recipes that they have tried, 'tested and approved', and encourage members to do the same. Officially, the reasons for these injunctions have to do with the pleasure one gets from enjoying dishes that are tasty, and yet completely point-efficient. By doing so, the program also introduces members to new food and tastes, and more specifically, as we've seen above, to middle and upper class food.

More generally, during meetings, recommendations are made on the members' lifestyles, and extend far beyond issues of food, touching on extremely varied 
public health issues such as sun protection or maintaining intellectual activity during old age:

- Martine is discussing vegetables, their vitamins. The subject of beta carotene comes up - it 'contributes to preparing your skin for the sun, but be careful, it doesn't protect you from the rays and doesn't replace sunscreen!'. - Responding to a member's question: 'so do you have to count [points] your whole life if you don't want to regain weight?', Martine claims that the idea is not to make members count their whole lives, that that's not the point, but 'once in a while, at some points in your life, you'll have to count again. And after all, counting is as good a way as any other to make your neurons work, right? Last week, we were talking about all the things you can do to make your brain and your memory work when you get a little bit older - well, counting [points] is a way of exercising!'

In these instances, the program plays the role of a reform institution, designed to promote official and legitimate definitions of well-being, definitions and practices that are also located within the social space of social classes. It also encourages members to resemble a portrait of the good middle-class housewife that I can now outline.

The first thing is to be 'organized', a keyword that Martine uses in almost every meeting. Planning grocery shopping (selecting purchases on the basis of the basic products needed and the recipes scheduled), doing the shopping in advance, preparing meals in advance, cooking large quantities of food and deep-freezing them, making sure never to be unprepared ('Going “oh, there's only a pizza left in 
the freezer, well, that's what we're going to have to eat", that shouldn't happen to you!'). Being organized and planning for everything are necessary as far as food is concerned, but this also applies to life in general:

It's early December. Martine starts the meeting by asking members individually about their plans for Christmas. 'Oh, I haven't really thought about that yet, it's still in a long time, we're not there yet!', a member says. 'Three weeks is not much!', Martine snaps back, pretending to be horrified. She says that she has already bought all the food she might need and stored it or put it in the freezer. On Christmas Eve, she will only have to get fish and seafood from the fishmonger (she has obviously already reserved them)... She has also already bought and wrapped presents for the whole family, especially for the kids since 'if you wait too long, they run out of the toys they asked you to get, and you know how kids are, they want this one, and not that one!'

Such a sense of prevision and anticipation echoes the 'Entertaining means planning' ( 'Recevoir c'est prevoir') and the disposition for planning ahead characteristic once again of middle-class taste (Bourdieu, 2010: 322) and means (since the whole process described by Martine can be quite expensive).

As is already shown in the previous excerpt, one of the key mechanisms used to promote the model of the good housewife lies in the - explicit or implicit injunctions to follow the example of the leader and her lifestyle. This common principle of support groups (the leader is a former member, who has 'been through' the same process and whose biographical experience gives her 
competence and legitimacy) is always likely to work as a mode of moralization and imposition of a class-based outlook - for instance when Martine presents the details of her everyday, upper middle class life as 'what you should do' (implying in order to lose weight, but also to lead a 'good' life), for example when she tells the group that on Christmas eve, twenty-eight people, including ten children, are coming over to eat at her place, or explain her organization and the way the evening will unfold in detail.

Lastly, this enterprise of moralization materializes in the use of a register that constantly draws from alimentary, economic and moral lexical fields and swings back and forth between these vocabularies, with the injunctions to 'save' or to 'bank' points. In terms of diet, this means banking points during the week (by not spending one's entire daily points allowance and saving some for 'weekend treats'). But clearly the program also encourages members to manage their lives like good, sensible housewives:

- Just like you save money on your bank account, you save points. You shouldn't eat on credit, in order to avoid paying charges on the scales! (Martine)

- You shouldn't eat on credit! I know that when I tell myself: 'well, I haven't saved anything but I'm going to give in anyway, I'll get those points back next week', well there's always something to prevent me from getting the points back the following week, and on the contrary, I end up accumulating debt until I can't pay it back any longer! So, never again! (Martine). 
Members are therefore supposed to be shaped into 'women who save', which echoes the 'propensity to accumulation', the asceticism, and even 'the almost insatiable thirts for rules of conduct which subjects the whole life to rigoureus discipline' of once again middle-class taste (Bourdieu, 2010: 330). Since it teaches cooking and obeying lifestyle standards defined by public health policies, while recommending an organization based on respecting festive and family traditions, following the example of the leader - including her deviances and weaknesses, and ceaselessly emphasizing the virtues of anticipating and saving, I contend that this weight less group is an enterprise of moralization and conversion from lower-class to middle-class.

\section{A case of/for Studying Institutional Socialization}

Three main results can be drawn from this study of a commercial weight loss group. First, the group can be interpreted as a 'people changing institution', and such a concept is still relevant to analyze contemporary institutions. It draws the attention on the influence of institutions on people, and mainly on the way they shape them, the way they make them by making them do things. Such a type of institutional making of the individual seems all the more interesting to study as, while sociology devotes little attention to it, ordinary and media representations on the subject are numerous and thriving, for instance through the figure of the 
coach or coaching as a principle of remodelling and controlling the individual, or that of television make-over - extreme or not -, or our present research interest, the commercial weight loss group.

But in order to manage or even to envision such a modification, an institution has to get a sufficient hold on people. That's why this first result is not to be separated from the second one, that is to say the fact that this People changing institution relies on an extensive social control over members.

We've seen the diverse and elaborate repertoire of means of control used by the institution — control being after all what members may be looking for-, and the pivotal role played by the written word in this arsenal. The visibility of the control is all the more striking it is a direct form of control, explicitely exerted, and applied through specific techniques and systems. It seems that sociologists tend to see more and more control through an Eliasian paradigm (Elias, 1969), insisting so heavily on self-control that institutional control almost disappears behind its supposed individual internalization and delegation. The downside of such a perspective lies in neglecting the application of direct institutional control on contemporary individual practices, and the reshaping of individuals by institutions - both points whose importance I have conversely emphasized and that I suggest to apply to other contemporary institutions.

Last, this Social control-, People changing institution, is also a 'People elevating institution'. The transformative aim of the institution is to be located within the social space of social classes, and refered to social structure: the institutional project consists in a class conversion of behaviors. These findings are certainly 
not specific to the particular fieldwork on which this article is based, and could well be found outside France. Although it is never described in American studies of commercial weight-loss groups, such a class project is most probably also at play in the United States, where the social distribution, and the social connotations of body size are also embedded in the social structure (Saguy, Gruys, 2010). One major difference would however be the intertwining of three, and not two, variables, both in terms of dispositions and practices and in terms of (self)representations : in the US context, race would be as important as class and gender, since the 'universe of class bodies' is also a racialized one. A comparison of similar French and American commercial weight-loss groups would be all the more interesting as these countries offer a fruitful case for comparative research on the social construction of bodies (Saguy, Gruys, Gong, 2010 : 587).

Such an analysis could furthermore be applied to other studies of institutional aims, and to the study of individual trajectories within institutions, by trying to locate not only practices but also aims, directions, wished trajectories within the social space. More generally, I actually contend that both the modalities of the control applied in transforming institutions, and the position of their transforming project in the space of social class, should be systematically taken into account in the analysis of 'people changing institutions'.

I would now like to expand a bit and suggest the implications of this analysis for further research, especially in the study of institutional socialization and individual change. The institutions' transforming effects on individuals can be divided into three broad categories (Darmon, [2006] 2010). Some institutional 
socializations are reinforcing socializations - with fixating rather than transforming effects on individuals, merely reinforcing pre-existing dispositions or attitudes. Other institutional socializations may be defined as transforming socializations, applied in a specific field (e.g., a given practical domain, the body, cultural practices, etc.) with various degrees (these transformations are by definition limited). Lastly, other institutional socializations may be referred to as converting socializations, due to the radicality and the extensiveness of the transformations they cause in members or participants as individuals.

In the case of the commercial weight loss group studied here, there is one shared dimension to the two main results I have established: the radicality of the institutional project at work here. Indeed, first, the extension of control and of the panopticon is meant to ensure a sufficient hold on participating individuals to allow a significant transformation of behaviors - we are thus dealing with a conversion institution. The issue of the type of control exerted, as I have shown, is tied with that of the 'limits' of the controlling institution. Analyzing the latter, I have outlined the moving boundaries of an institution that, from an explicit 'locus' of control - the leader, a 'judge behind the table', seeks to extend to the group of members, friends and relatives, the domestic sphere, and the dispositions of the member herself, with the help of many objects, among which writing and the written word play a major role. This control is an institutional, interactional, dispositional and written control. But the weight loss group can also be described as a conversion institution for a second reason: the institutional project is also a 
radical one because it is not limited to weight loss, but rather it constitutes more generally an upward trajectory in terms of social class.

As previously mentioned, I will not dwell on the actual efficacy of the system and the effectiveness of the conversion undergone - especially as, in order to occur, this conversion seems to require social conditions of possibility, including in terms of relationship to writing, that are not met in all social milieus. The written tools of surveillance and self-surveillance are both powerful and tenuous: powerful because of their number, their spatial and temporal ubiquity, their power to define the members' worlds; and tenuous because of the conditions required for their use. Indeed, their strength depends on the existence in members of dispositions to perceive them, operate them and feel their effects. I do not have unqualified evidence of this at this stage in my research, but it appears very likely that these dispositions for the use of writing are not randomly distributed in the social space. As it develops, I will be eager to analyze the potential discrepancy between this perception of the institution as a systematically lower-class habitus reforming apparatus and its reliance on writing as a privileged means of remote control - which presupposes a scholastic relationship to the written word (Goody, [1977] 1995). In the study of member practices and relationship to the system analyzed here, I will certainly be led to observe cases of successible conversion whose actual effects and duration should also be assessed - but also figures of impossible conversion, when members quit or simply can't manage to follow rules and principles that are way too foreign or unusual from them. In this sense, this system provides fertile ground for observation, beyond issues of body 
transformations, and for the analysis of institutional socializations and their effects.

i Ellen Granberg's analyses of narratives of people having lost weight through Weight Watchers and Overeaters Anonymous (Granberg, 2006, 2011) also show that the institutional discourse influence the way these weight-loss are conceived and told even long afterwards.

ii Stinson (2001: 137-40) also points out this role of 'continuous surveillance' played by co-members and by the member's domestic group.

iii The program primarily promotes self-control as a means of coercion (Stinson, 2001), but it is not necessarily the most efficient one. Indeed, I posit the hypothesis, which is supported by observation but requires further investigation from the members' point of view, that selfcontrol is rather a distant goal to reach, that never entirely obscures the exertion of institutional control - whether because the latter is not sufficient to bring about the internalization of the dispositions that would make it unnecessary, or because of member turnover. 


\section{References}

Adamek, R. J. and E. Z. Dager (1968) 'Social Structure, Identification and Change in a Treatment-Oriented Institution', American Sociological Review 33(6): 931-44.

Becker, H. S. (1968) 'The Self and Adult Socialization', in Norbeck, PriceWilliams and McCord (eds) The Study of Personality, pp. 194-208. New York: Holt, Rinehart and Winston.

Becker, H. S., B. Geer, E. C. Hughes and A. L. Strauss ([1961] 2004) Boys in White. New Brunswick: Transaction Publishers.

Berger, P. L. and T. Luckmann ([1966] 1991) The Social Construction of Reality. London: Penguin Books.

Bourdieu, P. ([1984] 2010) Distinction. A Social Critique of the Judgement of Taste. Oxon: Routledge.

Bourdieu, P. and J.-C. Passeron ([1977] 1990) Reproduction in Education, Society and Culture. London: Sage.

Darmon, M. ([2006] 2010) La Socialisation. Paris: Armand Colin.

Darmon, M. (2009) 'The Fifth Element: Social Class and the Sociology of Anorexia', Sociology 43(4): 717-33.

De Saint-Pol, T. (2010) Le Corps désirable. Paris: PUF.

Durkheim, E. ([1938] 1990) L'Évolution pédagogique en France. Paris: PUF. 
Elias, N. (1969) The Civilizing Process. Oxford: Blackwell.

Foucault, M. (1995) Discipline and Punish: the Birth of the Prison. New York: Vintage.

Garfinkel, H. (1956) 'Conditions of successful degradation ceremonies', American Journal of Sociology 61(5): 420-4.

Goffman, E. (1961) Asylums. Essays on the Social Situation of Mental Patients and Other Inmates. Garden City, NY: Doubleday.

Goody, J. ([1977] 1995) The Domestication of the Savage Mind. Cambridge: Cambridge University Press.

Granberg, E. (2006) 'Is that all there is? Possible Selves, Self Change, and Weight Loss', Social Psychology Quarterly 69(2): 109-26.

Granberg, E. (2011) 'Now my old self is thin: Stigma exit after weight-loss', Social Psychology Quarterly 74(1): 29-52.

Hasenfeld, Y. (1972) 'People Processing Organizations : An Exchange Approach', American Sociological Review 37(3): 256-63.

Heyes, C. J. (2006) 'Foucault goes to Weight Watchers', Hypatia 21(2): 126-49. Janowitz, M. (1969) Institution Building in Urban Education. New York: Russell Sage Foundation.

Lahire, B. (1998) L'Homme pluriel. Paris: Nathan.

Lahire, B. (2005) 'Fabriquer un type d'homme "autonome": analyse des dispositifs scolaires', in B. Lahire (ed) L'Esprit sociologique, pp. 322-47. Paris: La Découverte. 
Latour, B. and S. Woolgar ([1979] 1986) Laboratory Life. The Construction of Scientific Facts. Princeton NJ: Princeton University Press.

Martin, D. (2002) 'From appearance tales to oppression tales', Journal of Contemporary Ethnography 31(2): 158-206.

Merton, R. K., G. C. Reader and P. L. Kendall (eds.) (1957) The Student physician. Cambridge: Harvard University Press.

Murphy, E. and R. Dingwall (2001) 'The Ethics of Ethnography', in P. Atkinson, A. Coffey, S. Delamont, J. Lofland and L. Lofland (eds) Handbook of Ethnography, pp. 339-51. Los Angeles: Sage.

Régnier, F., A. Lhuissier and S. Gojard (2006) Sociologie de l'alimentation. Paris: La Découverte.

Saguy, A. and K. Gruys (2010) 'Morality and Health: News Media Constructions of Overweight and Eating Disorders', Social Problems 57(2): 231-50.

Saguy, A., Gruys, K. and S. Gong (2010) 'Social Problems Construction and National Context: News Reporting on "Overweight" and "Obesity" in the United States and France', Social Problems 57(4): 586-610.

Stinson, K. M. (2001) Women and dieting culture. Inside a commercial weightloss group. New Brunswick NJ: Rutgers University Press.

Strauss, A., L. Schatzman, R. Bucher, E. Danuta and M. Sabshin (1964) Psychiatric Ideologies and Institutions. New York: The Free Press of Glencoe. Street, D., R. D. Vinter and C. Perrow (1966) Organization for Treatment : A comparative Study of Institutions for Delinquents. NY: The Free Press. 
Tomlinson, G. (1986) 'Thought for Food: A Study of Written Instructions', Symbolic Interaction 9(2): pp. 201-16.

Wheeler, S. (1966) 'The Structure of Formally Organized Socialization Settings' in O. G. Brim and W. Stanton (eds) Socialization after Childhood: Two Essays, pp. 3-49. New York: John Wiley \& Sons. 